the Bronze Age. About 2100 B.c. Source: Iberia. Route: Brittany-Cornwall-Irish Sea. (4) The Late Bronze Age invasion. About 900 B.c. Source: Middle (and Lower?) Rhine and eastern, plus northern France. Route : Lowland BritainCumberland-Wigtownshire. (5) The La Tène wave. About 200 or 150 B.c. British Kelts coming from Wigtownshire occupied only a limited district of north-eastern Ireland.

Of these, (3) was certainly a non-Aryan movement. Much of the non-Indo-Germanic traits of ancient Ireland must be due to it. (4), however, came from a region in which the Kelts were deeply rooted. It was probably the Keltic cradle ; while (5) was an aristocratic conquest by bands, who came apparently without their womenfolk.

In reference to the aims of future research, one thing stands out clearly. The rigid canons of European prehistory are applicable to Ireland only with considerable qualification. They hold good so far as the general sequence goes, but some periods culturally so far outweigh others as almost to eclipse them. The only cultural strata in Ireland which really matter are (1) the basically 'lithic' Riverford complex; (2) the megaliths, and the earlier part of the bronze age they signify; (3) the Late Bronze Age (and the Kelticization of the country it brought about); and (4) the Early Christian period. There are periods in which Ireland has an importance for all Europe quite out of proportion to its size, and others in which she is simply an appanage of Britain.

The international importance of Irish archæology is too well known to be stressed here. Its importance for British archæology is, if anything, even greater. The only area of western Europe which was never Romanized, not only contains the clue to all problems of free Caledonia, but Roman Britain, too, is not intelligible without the Keltic background, which can be unfolded by research in Ireland. No problem in Irish archæology can be solved without the British evidence; but is there any problem in British archæology which can be solved without Irish evidence?

\title{
Tenth International Congress of Chemistry
}

\section{$\mathrm{T}$} HE Tenth International Congress of Chemistry met in Rome on May 15-21. More than thirty nations sent representatives, two thousand eight hundred in all; they included about seven hundred from Germany, two hundred from France and seventy-five from Great Britain.

Proceedings were opened at the Capitol in the presence of His Majesty the King of Italy with an address on the "Conquests of Chemistry" delivered by the president of the Congress, His Excellency Prof. N. Parravano of the University of Rome, and this was followed later by a reception by the Minister of National Education in the stadium of the Palatine-two sites of impressive and historic dignity.

The business of the Congress was conducted in the fine modern rooms of the recently built Citta Universitaria, in which the large hall set apart for the meetings was filled to overflowing during the opening addresses of the various sections.

Among those who opened the sections were Prof. P. Walden, on "The Creed of Scientific Chemistry" ; Prof. C. N. Hinshelwood, on "Physical Chemistry and Modern Scientific Thought", delivered in fluent Italian; Prof. Swietosławski, on "Developments of Industrial Chemistry"; Prof. Jolibois, on "Transformation of Matter and Motive Power" ; Prof. Giordani, on "The Utilisation of Thermal Energy"; Prof. Votocek, on
"Synthesis of Carbohydrates"; Dr. Hissink, on "The Chemistry of Soils"; Dr. L. M. Lampitt, on "The Trend of Food Science"; Prof. E. von Euler, on "Vitamins and Hormones in Food and in the Human Organism"; Prof. Ruggli, on "Housing, Furnishing and Clothing in their Chemical Aspects" ; Prof. Viviani, on "Natural and Artificial Textiles"; Prof. Fourneau, on "The Progress of Therapeutic Chemistry"; Prof. Butenandt, on "New Problems in Biological Chemistry"; Prof. Seyewetz, on "Chemistry and Photography"; Dr. S. E. Sheppard, on "Optical Sensitising of the Silver Halides"; Dr. Fr. ter Meer, on "New Developments in Chemical Technology"; Prof. G. Egloff, on "Petroleum-its Chemical and Industrial Significance"; Prof. D. M. T. Bogert, on "Chemistry and Defence"; Prof. H. Mark (not present) on a similar subject; Prof. Fr. Fischer, on "Chemistry and the Motor"; and Prof. Portevin, on "Metallurgy in Transport".

The President's opening speech and summaries of the above addresses in various languages were collected in a small volume and distributed at the end of the Congress, while in La Chimica $e$ l'Industria for May $(20,251$; 1938) will be found notes on the very numerous individual contributions to the sections together with photographs and short biographies of the presidents, vice-presidents and opening lecturers of each section. 
Thus, not only was the Congress well organized, but it was also carefully documented. In addition to the above-mentioned documents, Prof. Parravano made a gift to the members of a valuable collection he had compiled of Italy's chemical achievements, "La Chimica in Italia" (535 pp. illustrated).

It was surely with pardonable pride that the Italians took pains that the sights of their incomparable city should be shown to the visitors. Opportunities were given for the Congress members to view the excavations of the Forum Romanum and the other fora recently opened up, and to visit the reclaimed Campagna. The excavations at Ostia and the Lido of Rome were visited, an expedition was made to the Villa d'Este at Tivoli and Frascati, and in Rome itself the Augustean Exhibition with its admirably arranged presentment of Rome throughout the ages was thrown open. For the ladies, tours were arranged daily to see in detail the churches, historical monuments, museums and villas of Rome.

For the efficient work of the secretariat only the highest praise can be given; frequent comment was made on the courtesy and instant helpfulness shown to members.

Among the social events must be mentioned the reception by the Governor of Rome, the symphony concert, the gala performance in the opera, at which were performed a new opera, "Il Rey" and, what will always remain in the memory of the visitors, "Cavalleria Rusticana" conducted by its composer, Mascagni, with Gigli singing the chief part.

Tours were arranged after the Congress and these included visits to chemical and electrochemical works, notably Prince Genori Conti's factories for boric acid and the production of carbide and cyanamide at Terni. Here enormous quantities of water-power are developed and used for the production of calcium carbide, which is converted into the fertilizer cyanamide by heating it in the presence of nitrogen obtained from fractionation of liquid air.

It will thus be gathered that the Tenth was a most successful Congress, in which was displayed the present state of knowledge in most branches of chemistry, in incomparable surroundings and with an abounding hospitality under the direction of the genial president, His Excellency, Prof. Parravano.

Among those from Great Britain and Eire attending the Congress were Sir Robert Mond, Sir William Pope, Sir Robert Robertson, Sir Gilbert Morgan, Profs. Donnan, Barger, Dillon, Dodds, Heilbron, Hinshelwood, Ingold, Nolan, Norrish, Robinson, Thorpe, Reilly, Dr. Fox, Dr. Lampitt, Dr. Jordan, and Messrs. W. A. S. Calder, A. Marshall and J. D. Pratt. The British visitors and the ladies with them met together at a luncheon and were entertained to dinner by Sir Robert and Lady Mond with their customary gracious hospitality.

The Eleventh Congress of Chemistry will be held in London in 1941 about the time of the celebrations of the centenary of the Chemical Society.

Towards the end of the Congress, the Council of the International Union of Chemistry met, and received reports from its numerous committees. President Parravano demitted his office, and as president of the Union for the ensuing term, Prof. M. T. Bogert, of Columbia University, New York, was elected. M. Jean Gérard, the very efficient secretary of the Union, was re-elected to that office.

\section{Obituary Notices}

\section{Dr. W. Eagle Clarke, I.S.O.}

\section{$\mathrm{T}$} HE latter half of the nineteenth century saw the foundations laid of modern knowledge of bird migration, and Dr. Eagle Clarke was a leading exponent of the new methods in Great Britain. The idea that birds followed definite routes had stimulated fresh collection and study of records in Europe, and when the British Association for the Advancement of Science formed a Bird Migration Committee in 1880, Eagle Clarke was chosen to prepare the final reports, the last of which was presented to the Southport meeting in 1903 . In the earlier days, intensive observation of the movements of birds in limited areas and co-ordination of results from many areas provided the information upon which interpretation of migratory journeys depended, for bird-ringing was not tested as a scientific method until Mortensen's efforts in Denmark in 1899.

Eagle Clarke developed particularly two effective ways of studying migration. By living in lighthouses and lightships and by enlisting the services of lightkeepers he was able to catch bird movements in full swing, and his repeated visits during seasons of migration to Fair Isle, isolated between the Orkney and Shetland Islands, gave that tiny resting place something of the fame which Gätke's observations had already brought to Heligoland. The results of his observations were published in two volumes, "Studies in Bird Migration" (1912). 